\title{
Veronica peregrina (Plantaginaceae): A new record for India
}

\author{
Shugufta Rasheed ${ }^{1}$, Anzar A. Khuroo ${ }^{1 *}$, Maroof Hamid', Insha Muzafar', Akhtar H. Malik \\ and G.H.Dar ${ }^{2}$ \\ ${ }^{1}$ Centre for Biodiversity \& Taxonomy, Department of Botany, University of Kashmir, Srinagar, \\ J \& K - 190 006, India \\ ${ }^{2}$ Centre for Biodiversity Studies, Baba Ghulam Shah Badshah University, Rajouri, J \& K -185 131, India \\ *E-mail: anzarak@gmail.com
}

\begin{abstract}
Veronica peregrina L. is reported from Kashmir Himalaya as new record for India. Taxonomic description, photographic illustrations and comparison of diagnostic characters with its closely similar species are provided to facilitate easy identification.
\end{abstract}

Keywords: Flora, Kashmir Himalaya, plant record, Veronica

\section{Introduction}

The genus Veronica L., one of the dominant genera in family Plantaginaceae, comprises of about 450 species in the World (Albach et al., 2004; Mabberley, 2008). The genus shows characteristic features of flowers being solitary, or in terminal or axillary bracteate racemes, ebracteolate, calyx 4-5-partite, corolla rotate, or tube cylindric, stamens 2, exserted, stigma subcapitate (Hooker, 1897). The genus was previously placed under Scrophulariaceae and it has been recently shifted to Plantaginaceae (Haston, 2009).

From the Indian subcontinent, 18 species of Veronica were reported in The Flora of British India (Hooker, 1897). Recently, Agnihotri et al., (2014) reported 35 species from India, out of which 32 species are confined to Indian Himalayan region. From the Western Himalaya, 28 species of this genus have been reported (Pennell, 1943). In the Western Himalayan state of Jammu and Kashmir (J \& K), various workers have reported a number of Veronica species from different regions: 25 species from Jammu, Kashmir and Ladakh regions (Stewart, 1972), 25 species from Kashmir and Ladakh regions (Aman et al., 2003), 8 species from Jammu region (Sharma \& Kachroo, 1981) and 7 species from Ladakh region (Kachroo et al., 1977). During recent floristic surveys of aquatic habitats in Srinagar, Kashmir Himalaya (Fig. 1), the authors collected hitherto unknown specimens of Veronica species. A critical study of these specimens using relevant taxonomic literature (Albach et al., 2004), online e-floras (Flora of China, 2017; Jepson eflora, 2017) and illustrations, the specimens were identified as Veronica peregrina L. (Table 1). A perusal of floristic literature (Hooker, 1897; Pennell, 1943; Stewart, 1972; Aman et al., 2003; Agnihotri et al., 2014) revealed that this species has not been recorded from India till date. Therefore, a detailed taxonomic description and photographs of diagnostic characters (Fig. 2) of the species are provided here to validate this new plant record for India and facilitate its easy field identification.

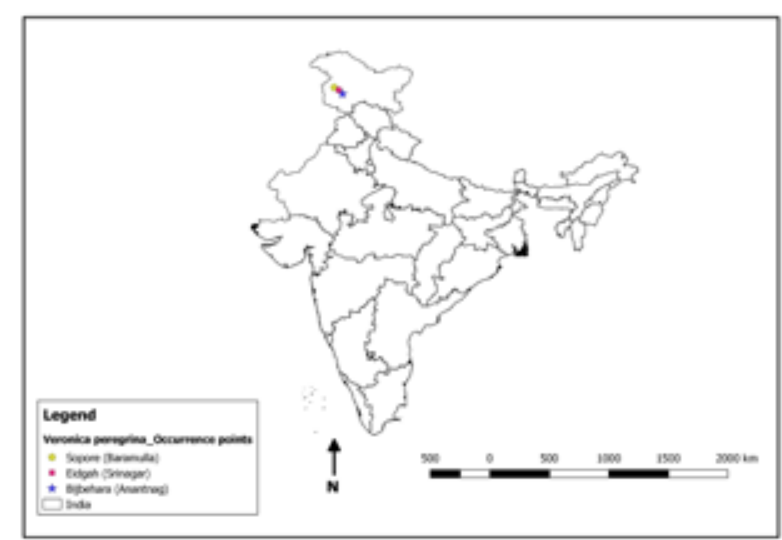

Fig. 1. Distribution of Veronica peregrina L. in India 
Table 1. Comparison of distinguishing characters between $V$. peregrina $L$., $V$. arvensis $L$. and $V$. verna $L$. growing in Kashmir Himalaya, India

\begin{tabular}{|c|c|c|c|}
\hline $\begin{array}{l}\text { Diagnostic } \\
\text { characters }\end{array}$ & V. peregrina & V. arvensis & V. verna \\
\hline Leaf blade & $\begin{array}{l}\text { Lower ones spathulate, } \\
\text { upper ones oblong }\end{array}$ & $\begin{array}{l}\text { Lower ones oval or ovate- } \\
\text { cordate, upper ones } \\
\text { lanceolate to linear }\end{array}$ & $\begin{array}{l}\text { Lower ones oblong, } \\
\text { pinnatisect, upper ones } \\
\text { deeply cleft into linear lobes }\end{array}$ \\
\hline Inflorescence & $\begin{array}{l}\text { Racemes terminal and } \\
\text { axillary }\end{array}$ & Racemes terminal & $\begin{array}{l}\text { Racemes terminal and } \\
\text { axillary }\end{array}$ \\
\hline Bract shape & Oblanceolate & Lanceolate & Lanceolate to linear \\
\hline Corolla & Usually white & Pale blue or whitish blue & Pale blue \\
\hline Pedicel & Up to $2 \mathrm{~mm}$ long & Up to $1 \mathrm{~mm}$ long & Up to $5 \mathrm{~mm}$ long \\
\hline
\end{tabular}

Veronica peregrina L., Sp. Pl. 1: 14. 1753. Fig. 2

Veronica chillensis Kunth, Nov. Gen. Sp. 2: 390.1817.

Veronica peregrina var. xalapensis (Kunth) Pennel, Torreya 19(9): 167. 1919.

Veronica sherwoodii M. Peck, Torreya 28(3): 56. 1928.

Annual herbs, 5-32 cm tall, multiple branches arise from the base of main erect stem; branches diffuse, decumbent, densely glandular pubescent. Leaves sessile, variable, lower spathulate, $c .1 .5 \times 0.3 \mathrm{~cm}$, withered in flowers and fruits stage, middle ones cauline, oblanceolate, $2.5 \times 0.5 \mathrm{~cm}$, upper ones narrowly oblong, c. $2 \times 0.4 \mathrm{~cm}$, crenate or entire at margin, cuneate at base. Racemes terminal and axillary, bracts alternate, oblanceolate, slightly smaller in size than the upper leaves, $1.3-1.5 \mathrm{~cm}$ long; pedicels less conspicuous, c. $2 \mathrm{~mm}$ long. Calyx 4-lobed, lobes narrowly oblong, $5 \mathrm{~mm}$ long, persistent in mature fruit. Corolla white, rotate, narrowly oblong to ovate, c. $4 \mathrm{~mm}$ long. Stamens 2, shorter than the corolla, seen only when flowers open. Stigma subcapitate, unlobed. Capsule obcordate, compressed, c. $3 \mathrm{~mm}$ long, $c$. $4 \mathrm{~mm}$ broad, margin short, glandular and ciliate, notched at apex. Seeds 45-60, oblong, smooth.

Specimens examined: INDIA: Kashmir (J\&K), Srinagar, Eidgah, $34.10^{\circ} \mathrm{N}, 74.79^{\circ} \mathrm{E}, 30.5 .2014$, Shugufta \& Khuroo 85 (KASH); Baramulla, Sopore, $34.28^{\circ} \mathrm{N}, 74.47^{\circ} \mathrm{E}, 21.5 .2014$, Shugufta \& Khuroo 311 (KASH); Anantnag, Bijbehara, $33.80^{\circ} \mathrm{N}, 75.10^{\circ} \mathrm{E}$, 27.5.2015, Shugufta \& Khuroo 312 (KASH).

Flowering $\mathcal{E}$ fruiting: May - June.


Fig. 2. Veronica peregrina L.: a. Habit; b. Flower with bract; c. Developing fruit with sepals \& bract; d. Mature fruit with persistent sepals; e. Fruit; $f$. Seeds.

Distribution $\mathcal{E}$ ecology: The plant is native to North America, South America and naturalized in Europe, Russia, China, Korea, Japan, Mangolia (U.S. National Plant Germplasm System, 2016). It usually grows in moist wastelands, damp sites, along roadsides and disturbed sites. 


\section{Acknowledgements}

Authors are thankful to Head, Department of Botany, University of Kashmir for providing necessary facilities, and to anonymous reviewers and Editor, Rheedea for their useful comments which have improved the quality of the text. The supporting staff at the Centre for Biodiversity and Taxonomy, University of Kashmir is also acknowledged for their kind help during the course of present study.

\section{Literature Cited}

Agnihotri, P., Dixit, V. \& T. Husain 2014. Conspectus of the genus Veronica L. (Plantaginaceae) in India. Pleione 8(1): 9-16.

Albach, D.C., Martinez-Ortega, M.M. \& M.W. Chase 2004. Veronica: Parallel morphological evolution and phytogeography in the Mediterranean. Plant Syst. Evol. 246: 177-194.

Aman, A., Dar, G.H. \& A.R. Naqshi 2003. Scrophulariaceae of the Kashmir Himalaya. Valley Book House, Srinagar, Kashmir. pp. 129-167.

Haston, E., Richardson, J.K., Stevens, P.F., Chase, M.W. \& D.J. Harris 2009. The linear angiosperm phylogeny group (LAPG) III: A linear sequence of the families in APG III. Bot. J. Linn. Soc. 161: 128-131.

Hooker, J.D. 1897. Flora of British India. Vol. 4. Bishen Singh Mahendra Pal Singh, Dehra Dun. pp. 291-297.

Kachroo, P., Sapru, B.L. \& U. Dhar 1977. Flora of Ladakh. Bishen Singh Mahendra Pal Singh, Dehra Dun. pp. 125-126.

Kunth, K.S. 1817. Nova Genera et Species Plantarum. 390p. Vol. 2. http://www.tropicos.org/ Name/29200239. (Accessed on 18.04.2018).

Linnaeus, C. 1753. Species Plantarum. 14p. Vol. 1. http://www.tropicos.org/Name/29200239. (Accessed on 18.04.2018).
Mabberley, D.J. 2008. The Plant-Book: A portable dictionary of plants, their distribution and uses. $3^{\text {rd }}$ edn. Cambridge University Press, Cambridge, UK. p. 744.

Peck, M.O. 2018. Torreya. 56p. Vol. 28. http:// www.tropicos.org/Name/29200239. (Accessed on 18.04.2018).

Pennell, F.W. 1919. Torreya. 167p. Vol. 19. http:// www.tropicos.org/Name/29200239. (Accessed on 18.04.2018).

Pennell, F.W. 1943. The Scrophulariaceae of the Western Himalayas. Bishen Singh Mahendra Pal Singh, Dehra Dun. pp. 73-91.

Sharma, B.M. \& P. Kachroo 1981. Flora of Jammu and Plants of Neighbourhood. Bishen Singh Mahendra Pal Singh, Dehra Dun. p. 241.

Stewart, R. 1972. An annotated catalogue of vascular plants of West Pakistan and Kashmir. Fakhri Printing Press, Karachi. pp. 663-667.

\section{Web links:}

Flora of china: Available at: www.efloras.org (Accessed on 18.04.2017).

Jepson eFlora: Available at: http://ucjeps.berkeley. edu (Accessed on 18.04.2017).

National Plant Germplasm System, U.S. 2016. https://npgsweb.arsgrin.gov/gringlobal/ taxon/taxonomysearch.aspx (accessed on 18.04.2017).

Received: 21.04.2017

Revised and Accepted: 14.06.2018 